\title{
СОЦІАЛЬНЕ ЗАБЕЗПЕЧЕННЯ ТА СОЦІАЛЬНИЙ ЗАХИСТ В УКРAї̈I
}

\section{SOCIAL SECURITY AND SOCIAL PROTECTION IN UKRAINE}

\author{
Бондар Микола Іванович \\ доктор економічних наук, профресор, \\ ДВНЗ «Київський національний економічний університет \\ імені Вадима Гетьмана», \\ ORCID: https://orcid.org/0000-0002-1904-1211
}

\author{
Bondar Mykola \\ Kyiv National Economic University named after Vadym Hetman,
}

\begin{abstract}
Стаття присвячена актуальним питанням обґрунтування сутності соціального захисту та соціального забезпечення населення країни. Проаналізовано стан нормативно-правового регулювання соціального забезпечення та систематизовано фрактори інноваційного територіального розвитку. Охарактеризовано основні існуючі наукові підходи щодо законодавчого регламентування прав соціального забезпечення населення. Визначено структурні елементи соціального захисту. Досліджено світовий досвід реалізації державної політики щодо соціального захисту різних країн Європи та Америки. Визначено шляхи реалізації ефективної державної політики щодо соціального захисту населення. Окреслено основні моделі систем соціального захисту громадян. Проведено аналіз джерел формування фрондів на покриття витрат соціального забезпечення.

Ключові слова: соціальний захист, соціального забезпечення, соціальне страхування, соціальна безпека, пенсійне забезпечення, допомога по тимчасовій непрацездатності, система соціального страхування.
\end{abstract}

Статья посвящена актуальным вопросам обоснования сущности социальной защиты и социального обеспечения населения страны. Проанализировано состояние нормативно-правового регулирования социального обеспечения и систематизированы фракторы инновационного территориального развития. Охарактеризованы основные существующие научные подходы к законодательному регламентированию прав социального обеспечения населения. Определены структурные элементы социальной защиты. Исследован мировой опыт реализации государственной политики по социальной защите разных стран Европы и Америки. Определены пути реализации эфффективной государственной политики по социальной защите населения. Обозначены основные модели систем социальной защиты граждан. Проведен анализ источников фрормирования фрондов на покрытие расходов социального обеспечения.

Ключевые слова: социальная защита, социальное обеспечение, социальное страхование, социальная безопасность, пенсионное обеспечение, помощь по временной нетрудоспособности, система социального страхования.

The article is devoted to the key issues of substantiation of the essence of social protection and social security of the population. The main purpose of this article is to study the existing approaches to substantiation of the essence of "social protection" and "social security", study the experience of European countries in the formation of sources of social costs and discuss ways to improve them. Considering the essence of social security, the article analyzes the state of its legal regulation, systematizes the main factors of innovative territorial development of the country. The main existing scientific approaches to the legislative regulation of social security rights are described. It is proposed to consider social security as a system of state measures to provide material assistance in order to compensate, reduce or prevent the negative impact of social risks on persons who, due to circumstances beyond their control, do not have sufficient means of subsistence. Social protection should be considered as a practical activity in the implementation of the main directions of social policy through a set of organizational, legal and socio-economic measures. The structural elements of social protection are determined. The world experience of the implementation of the state policy on social protection in Europe and America has been studied. The ways of realization of the effective state policy on social protection of the population are defined. The basic models of social protection systems of citizens are outlined. It is determined that an effective state policy on social protection is implemented by setting its minimum levels and encourages the establishment of multilateral partnerships involving public, private and non-prof- 
it organizations, as well as international, national and local partners, especially in health and social protection. Based on official statistics, an analysis of the sources of funds for social security costs was made. The analysis of the social insurance system in different countries of the world showed that there is a certain gradation in the levels of insurance contributions depending on the population group. It is established that the system of social contributions is directly related to the level of social security in the country.

Keywords: social protection, social security, social insurance, pension provision, temporary disability benefits, social insurance system.

Постановка проблеми. Соціальне забезпечення є одним із ключових елементів економічного розвитку будь-якої країни світу. Саме тому при фрормуванні державної політики особливу увагу зосереджують саме на рівні та структурі соціального забезпечення. Варто відзначити, що структура соціального забезпечення в різних країнах відрізняється. Але ключовими елементами залишаються соціальне страхування, пенсійне забезпечення, допомога по тимчасовій непрацездатності та інші соціальні виплати та допомоги.

В наукових дослідженнях проблематики соціального захисту та соціального забезпечення приділено значну увагу формуванню інституційного удосконалення соціального захисту та організаційним аспектам реалізації процедур соціального захисту. Значна кількість різного трактування понять «соціальний захист» та «соціальне забезпечення», відсутність системного нормативно-правового регулювання політики соціального захисту в країні, постійні зміни в порядку нарахування соціальних платежів призводить до дестабілізації соціальної безпеки населення та відсутності мотивацій щодо повноти сплати соціальних внесків і платежів.

Тому питання щодо удосконалення сутності соціального захисту та соціального забезпечення, дослідження щодо обсягу навантаження на юридичних та фрізичних осіб щодо сплати соціальних внесків $€$ актуальними і потребують наукового обґрунтування.

Аналіз останніх досліджень і публікацій. Дослідженню теоретичних засад соціального захисту населення, його змісту та структури присвячено значну кількість наукових праць авторів, серед них: Лукащикевич В. [6], Маршавін Ю.М. [7], Руженський М.М. [15], Слюсаренко К.В. [16], Смирнова І.І. [17], Стельмащук Ю. [19] та багато інших. Проте, всі ці результати ґрунтуються на відокремлених дослідженнях соціального захисту та соціальної безпеки населення, не враховуючи аналіз джерел формування коштів на покриття соціальних гарантій.

Формулювання цілей статті. Не зважаючи на значну кількість наукових досліджень щодо соціального захисту населення, враховуючи їх значимість та глибину дослідження, залишаються дискусійними питання щодо розуміння понять «соціальний захист» та «соціальне забезпечення», обґрунтування порядку фрормування джерел покриття витрат на соціальний захист населення в порівнянні з різними країнами.

Метою даної статті $\epsilon$ оцінка існуючих підходів щодо обґрунтування сутності понять «соціальний захист» та «соціальне забезпечення», дослідження досвіду європейських країн щодо фрормування джерел покриття соціальних витрат та обґрунтування шляхів їх удосконалення.

Виклад основного матеріалу дослідження. Відповідно до визначення Міжнародної асоціації соціального забезпечення, соціальне забезпечення може включати програми соціального страхування, програми соціальної допомоги, універсальні програми, схеми взаємної вигоди, національні ощадні фонди та інші механізми, включаючи ринкові підходи, які відповідно до національного законодавства або практики є частиною системи соціального страхування. забезпечення країни.

Статтею 46 Конституції України гарантовано право громадянина на соціальний захист, що включає право на забезпечення їх у разі повної, часткової або тимчасової втрати працездатності, втрати годувальника, безробіття з незалежних від них обставин, а також у старості та в інших випадках, передбачених законом [5]. Також цією статтею Конституції акцентовано, що це право гарантується загальнообов'язковим державним соціальним страхуванням за рахунок страхових внесків громадян, підприємств, установ і організацій, а також бюджетних та інших джерел соціального забезпечення; створенням мережі державних, комунальних, приватних закладів для догляду за непрацездатними.

Відповідно до Закону України про загальнообов'язкове державне соціальне страхування [14], визначають шість видів загальнообов'язкового державного соціального страхування: пенсійне; у зв'язку з тимчасовою втратою працездатності; медичне; від 
нещасного випадку на виробництві та профеесійного захворювання, які спричинили втрату працездатності; на випадок безробіття та інші види страхування, передбаченні законами України. Отже, система соціальних виплат та допомог має різні види і призначається для різних груп населення.

Поширеною $€$ думка, що виникнення терміну і поняття «соціальний захист» пов'язане із прийняттям закону США про соціальний захист (Social Security Act) у 1935 році. [9, с. 256]. Проте існують й інші думки щодо виникнення цього поняття [7, с. 42].

Розглядаючи сутність соціального забезпечення в Україні, слід відзначити широкий спектр різних авторських підходів до його трактування [3, с. $103 ; 4$, с. $149 ; 19$, с. 107]. Існуючі розбіжності в тлумаченні поняття соціального захисту, нечіткість у визначенні його мотивів, інструментів та суб“єктів здійснення цього захисту знижують ефрективність державної соціальної політики, звужують об“єктну базу та розмивають рамки і межі надання адресної підтримки соціально незахищеним верствам населення [15, с. 21].

В. Лукащикевич зазначив, що у вітчизняних наукових працях до 60-х років термін «соціальний захист» не використовувався, натомість офріційним було застосування терміну «соціальне забезпечення» [6].

Нині дослідженню проблем соціального захисту та соціального забезпечення присвячено праці науковців різних галузей наук та спеціальностей, проте найбільшу питому вагу приділено в юридичній та економічній сорерах.

М. Даніліна стверджує, що соціальний захист - це система заходів правового, соціально-економічного та організаційного характеру, що гарантується і реалізовується державою для забезпечення гідного життя, тобто матеріальної забезпеченості на рівні стандартів сучасного розвитку суспільства і вільного розвитку людини [2, с. 26]. О. Новікова соціальний захист обґрунтовує як процес соціальної безпеки населення [10].

До соціальної безпеки Суханова А.В. відносить: стан гарантованої правової та інституціональної захищеності життєво важливих соціальних інтересів особи й суспільства від внутрішніх і зовнішніх загроз; захищеність життєво важливих інтересів людини і громадянина, суспільства і держави, за якої забезпечується сталий розвиток суспільства, своєчасне виявлення, запобігання і нейтралізація реальних і потенційних загроз національним інтересам; стан суспільства, за якого забезпе- чується нормальне відтворення суспільства як демограсрічної популяції, як нації, як народу; стан життєдіяльності людини та суспільства, що характеризується сорормованою, сталою соціальною системою забезпечення соціальних умов діяльності особистості, її соціальної захищеності, стійкості до впливу чинників, які підвищують соціальний ризик [20].

І.І. Смирнова, О.Ю. Лихошва, Н.В. Рак, Л.А. Горієва соціальний захист визначають на основі таких складових; соціальне забезпечення, соціальне страхування, соціальна допомога [17].

Дослідивши існуючі наукові підходи щодо законодавчого регламентування прав соціального забезпечення населення О. Гузенко та Т. Хайлова зробили висновок, що одним із напрямків, який на цей час потребує поглибленого дослідження, це принципи права соціального забезпечення [1, с. 21], адже відсутність таких принципів робить неоднозначним дотримання законодавства в сорері соціального забезпечення.

На сьогодні в Україні немає єдиного нормативного документу, який регулював би всі аспекти соціального захисту населення. Соціальне забезпечення розглядається як система державних заходів щодо надання матеріальної допомоги 3 метою компенсації, зниження або запобігання негативного впливу соціальних ризиків на осіб, які через незалежні від них життєві обставини не мають достатніх засобів до існування. Це фрорма вираження політики держави, спрямованої на матеріальне забезпечення окремих категорій громадян (за рахунок частини державного та місцевих бюджетів, фондів соціального страхування, позабюджетних фрондів [11, с. 8]. Тоді як соціальний захист є практичною діяльністю, яка полягає у реалізації основних напрямів соціальної політики завдяки комплексу організаційно-правових і соціально-економічних заходів. Мельник К.Ю. визначає соціальний захист як обов'язок суспільства, який реалізує держава, щодо утримання конкретної категорії громадян в особливих випадках та особливими засобами за рахунок суспільства завдяки мережі державних органів, органам місцевого самоврядування, громадським організаціям [8].

Питання нормативно-правового регулювання соціального захисту населення в Україні трактуються в численних нормативних актах різного спрямування (понад 150 законів, сотні постанов КМУ, більше тисячі відомчих і міжвідомчих наказів та розпоряджень). 
Головне те, що ці документи містять певні протиріччя, які сповільнюють або призупиняють реалізацію державної політики в ссрері соціального захисту. А також в різних нормативних документах можуть визначатися певні особливості реалізації державної політики щодо соціальних виплат чи допомог. Зокрема механізм забезпечення однієї і тієї самої соціальної виплати може по різному регламентуватися в різних законодавчих документах.

Отже, соціальний захист включає певні послуги щодо спеціального та додаткового соціального захисту, які передбачають різні види допомоги у стаціонарних установах, грошову допомогу, соціальні пільги і інші послуги, що надаються місцевим самоврядуванням.

Таким чином, не доцільно використовувати поняття «соціальний захист» і «соціальне забезпечення» як синоніми, оскільки «соціальний захист» $€$ більш ширшим поняттям і може включати в себе «соціальне забезпечення».

Основними правами людини, які визначено та закріплено у міжнародних нормативних документах, $є$ соціальний захист та право на соціальне забезпечення. Варто відзначити, що соціальний захист відіграє важливу роль у покращенні умов життя, скороченні бідності, сприянні інклюзивному зростанню та підтримці соціально-економічної стійкості. Але недостатній рівень соціального захисту в різних країнах світу свідчить про те, що громадяни не користуються своїми правами на соціальний захист.

Відповідно до інформації Міжнародної асоціації соціального забезпечення встановлено, що близько 50 відсотків населення світу мають доступ до тієї чи іншої форми соціального забезпечення, тоді як лише 20 відсотків мають достатнє охоплення соціальним забезпеченням [13].

Тому необхідність розширення охоплення різних груп населення $€$ ключовою проблемою для організацій соціального забезпечення у всіх регіонах. Однак це може бути зроблено лише при вирішенні питань, що включають демографрічне старіння населення, розвиток сімейних структур, наслідки економічної глобалізації, зростання несрормальних ринків праці, а також епідеміологічні та екологічні зміни.

За оцінками Міжнародної організації праці (МОП, 2021b) 64,3\% населення Північної та Південної Америки мають доступ принаймні до однієї з форм соціального захисту, при цьому 57,4\% дітей отримують допомогу з догляду за дитиною та 51,9\% матерів народжують. Більш висока частка $(88,1 \%)$ людей похилого віку отримують пенсії, а 71,8\% осіб з важкими фрормами інвалідності отримують допомогу із соціального захисту. Хоча програмами соціальної допомоги охоплено 36,7\% вразливих осіб, лише 16,4\% безробітних отримують допомогу із соціального захисту [13].

Отже, ефективна державна політика щодо соціального захисту реалізується шляхом встановлення мінімальних рівнів соціального захисту та спонукає до встановлення багатостороннього партнерства за участю державних, приватних та некомерційних організацій, а також міжнародних, національних та місцевих партнерів, особливо у галузі охорони здоров'я та соціального захисту.

В країнах-членах Європейського союзу виділяють чотири основні моделі систем соціального захисту громадян: континентальна (бісмарківська), англосаксонська (модель Беверіджа), скандинавська і південно-європейська.

В науковій літературі додатково виокремлюють ліберальну модель (усі англомовні країни, включаючи Велику Британію), консервативно-корпоративну модель (Бельгія, Німеччина, Франція) та соціал-демократичну модель (скандинавські країни). Проте це не вичерпаний перелік моделей систем соціального захисту, більш детальну класифрікацію моделей наводять в своїй праці К. Слюсаренко і М. Садовенко [16]. Система соціального страхування в кожній країні має свої особливості і звичайно має прямий взаємозв'язок із економічним розвитком країни. Варто відзначити, що аналіз системи соціального страхування в різних країнах світу показав, що існує певна градація за рівнями страхових внесків залежно від групи населення. Зокрема, це можна говорити про звичайних працівників та інвалідів, які сплачують страхові внески. Страхові внески, в свою чергу, покривають різні види страхових виплат та допомог.

Кожна $з$ цих моделей має свої особливості формування джерел та критеріїв розподілу покриття соціального забезпечення населення, що і характеризує рівень соціального захисту.

Для того, щоб забезпечити виплату пенсійних виплат за тим пенсійним віком, який визначений в Україні, потрібно мати певне фрінансування. А саме страхові внески і $€$ тим джерелом, з якого виплачуються пенсії та інші страхові та соціальні виплати. Варто відзначити, що за рахунок страхових внесків фрінансуються не тільки пенсійні виплати, але й інші страхові та соціальні виплати.

У табл. 1 показано основні особливості реалізації соціального страхування у різних 
Таблиця 1

Соціальне забезпечення за джерелами фрінансування

\begin{tabular}{|c|c|c|c|}
\hline $\begin{array}{c}\text { Джерело } \\
\text { фрінансування }\end{array}$ & Америка & Польща & Україна \\
\hline $\begin{array}{c}\text { Застрахована } \\
\text { особа }\end{array}$ & $\begin{array}{l}\text { 6.2\% заробітку, що } \\
\text { покривається }\end{array}$ & $\begin{array}{l}\text { 9.76\% заробітку, що } \\
\text { покривається (старість) } \\
\text { i 1.5\% (інвалідність } \\
\text { i годувальники). }\end{array}$ & Не має \\
\hline Роботодавець & $\begin{array}{l}\text { 6.2\% покритого фонду } \\
\text { заробітної плати. }\end{array}$ & $\begin{array}{l}\text { 9.76\% заробітку, що } \\
\text { покривається (старість) } \\
\text { i 1.5\% (інвалідність } \\
\text { і годувальники). }\end{array}$ & $22 \%$ \\
\hline Пенсійний вік & $\begin{array}{l}\text { Вік } 66 \text { років (поступово } \\
\text { зросте до } 67 \text { років до } \\
2027 \text { року) } 3 \text { охопленням } \\
\text { не менше } 40 \text { кварталів. }\end{array}$ & \begin{tabular}{|l} 
Вік 65 років 3 мінімум \\
25-річним охопленням \\
(чоловіки) або вік 60 \\
з мінімум 20-річним \\
страхуванням (жінки).
\end{tabular} & $\begin{array}{l}\text { Вік } 60 \text { років з охопленням } \\
\text { не менше } 35 \text { років } \\
\text { (чоловіки) або } 60 \text { років } \\
\text { (жінки) з охопленням } \\
\text { не менше } 30 \text { років. }\end{array}$ \\
\hline
\end{tabular}

Джерело: сформовано на основі даних [13]

країнах світу. Різниця полягає як у тому хто $€$ платниками та за рахунок кого фрормуються джерела фрінансування страхових та пенсійних виплат, але і у розмірі цих внесків.

Система соціальних внесків напряму пов'язана із рівнем соціального забезпечення в країні. Відповідно, чим вищий рівень соціальних внесків, тим більші витрати потрібно покривати. Якщо порівнювати Україну та США, то страхові внески сплачують як роботодавці, так і працівники, але відсоток страхових внесків в США значно менший, ніж в Україні. Таку ситуацію можна пояснити тим, що пенсійний вік в Україні значно нижчий, ніж в США чи в інших країнах. Саме тому від форомування дієвого механізму, в якому буде поєднано реальний розмір страхових внесків та система страхових та соціальних виплат, які потрібно профрінансувати, і залежить рівень соціального забезпечення в країні.

Отже, чим більший рівень страхових внесків, тим вищий розмір соціальних виплат. Тому актуальним як для України, так і для інших країн світу $€$ забезпечення прозорого та офріційного працевлаштування громадян, які будуть сплачувати страхові внески та особисто фрормувати джерело фрінансування власних соціальних виплат.

Окрім того, можна виокремити й інші виклики, які виникають при реалізації едективної системи соціального забезпечення. Серед них можна виокремити такі: недостатній рівень фрінансування системи соціального захисту; відсутність або недостатній рівень інвестицій в соціальний захист; непрозоре державно-приватне партнерство у забезпеченні соціального захисту; несрормальна зайнятість; фрункціонування адміністративних установ щодо надання соціальних послуг та інші виклики.

Однією із проблем $є$ саме державно-приватне партнерство, що є тим механізмом, який безпосередньо впливає на підвищення рівня соціального захисту та збільшенні фрінансування соціальних послуг. У Габоні, наприклад, оператори мереж мобільного телесронного зв'язку роблять значний внесок у фрінансування загальної охорони здоров'я, стягуючи 10-відсотковий збір 3 обороту, крім податків, та 1,5-відсотковий збір на грошові перекази за межі країни [13].

Високий рівень неформальної зайнятості та зростання нестандартних фрорм роботи (викликаний цифрровою економікою) також призводять до того, що дедалі більша частина населення має робочі місця, які, як правило, не покриваються існуючими механізмами соціального забезпечення. Це посилює і так складну ситуацію. Наприклад, зараз в Україні запроваджуються та офрормлюються юридичні відносини у вигляді гіг-контрактів.

Отже одним 3 основних показників соціально-економічного стану країни $€$ частка видатків у ВВП країни. Саме рівень соціального забезпечення та захисту в країні залежить від розміру фрінансування. Фінансування соціального захисту та забезпечення здійснюється за рахунок коштів загального та місцевого бюджету, але під впливом різних фракторів ця частка може змінюватися та напряму впливати на рівень соціального захисту громадян країни. На рис.1 схематично показано динаміку частки видатків на соціальний захист у структурі ВВП України.

Для порівняння рівня соціального захисту громадян України 3 іншими країнами доцільно проаналізувати динаміку та 


\section{ВИТРАТИ НА СОЦІАЛЬНИЙ ЗАХИСТ У \% ДО ВВП}

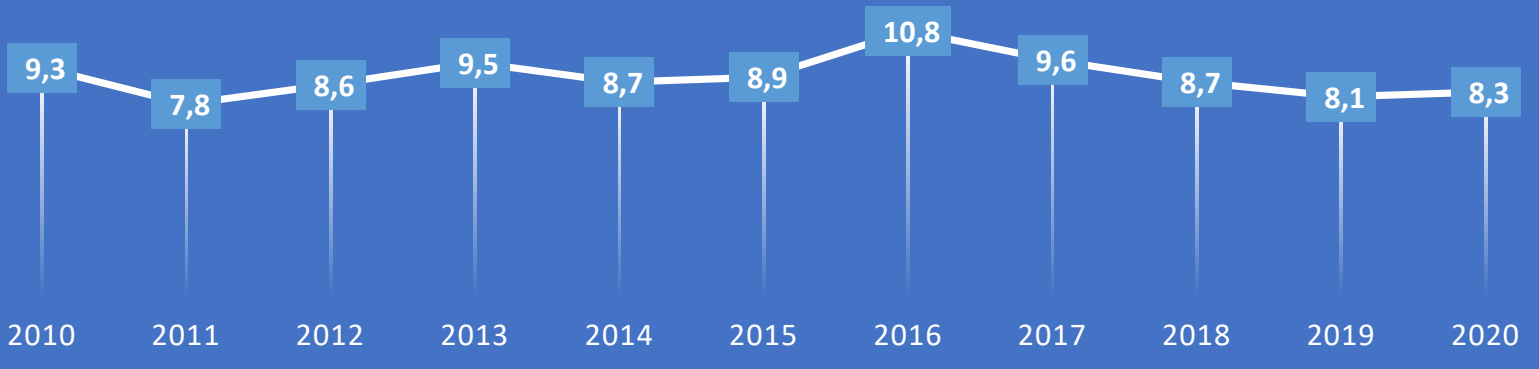

Рис. 1. Динаміка частки видатків зведеного бюджету України на соціальний захист та соціальне забезпечення у ВВП

Джерело: сорормована на основі [18]

частку витрат на соціальний захист країн $€ С$ та України у ВВП (табл. 2).

Отже, якщо порівнювати показник витрат на соціальний захист у складі ВВП країни, то в Україні цей показник один 3 найнижчих, а в деяких випадках менший майже у 4 рази. Хоча ставки нарахування платежів $€$ порівняно $з$ іншими країнами достатньо високі.

Аналізуючи ставки нарахування платежів (табл. 3) та частку ВВП, що спрямовується на соціальний захист населення, слід відзначити те, що підвищення рівня витрат на соціальний захист можливий лише за рахунок зростання економічних показників розвитку країни.

Висновки. На основі проведеного дослідження можна стверджувати, що в основу ідеології розвитку країни має бути покладено соціально орієнтована ринкова економіка для забезпечення соціальної безпеки населення. Соціальний захист має бути основним кри-

Таблиця 2

ВВП і витрати на соціальний захист країн ЄС та України у 2010-2019 рр.

\begin{tabular}{|c|c|c|c|c|c|c|c|c|c|c|}
\hline \multirow{2}{*}{ Країна } & \multicolumn{10}{|c|}{ Витрати на соціальний захист у \% до ВВП } \\
\cline { 2 - 12 } & $\mathbf{2 0 1 0}$ & $\mathbf{2 0 1 1}$ & $\mathbf{2 0 1 2}$ & $\mathbf{2 0 1 3}$ & $\mathbf{2 0 1 4}$ & $\mathbf{2 0 1 5}$ & $\mathbf{2 0 1 6}$ & $\mathbf{2 0 1 7}$ & $\mathbf{2 0 1 8}$ & $\mathbf{2 0 1 9}$ \\
\hline Україна & 9,3 & 7,8 & 8,6 & 9,5 & 8,7 & 8,9 & 10,8 & 9,6 & 8,7 & 8,1 \\
\hline Болгарія & 16,6 & 16,0 & 16,1 & 17,0 & 17,9 & 17,2 & 16,9 & 16,5 & 16,4 & 16,1 \\
\hline Німеччина & 28,7 & 27,5 & 27,6 & 28,0 & 27,8 & 28,1 & 28,4 & 28,4 & 28,5 & 29,1 \\
\hline Естонія & 17,2 & 15,3 & 14,7 & 14,6 & 14,6 & 15,8 & 16,2 & 15,7 & 16,1 & 16,1 \\
\hline Франція & 31,0 & 30,9 & 31,5 & 31,9 & 32,1 & 31,9 & 32,0 & 31,7 & 31,5 & 31,4 \\
\hline Польща & 19,2 & 18,3 & 18,5 & 19,2 & 19,0 & 19,0 & 20,3 & 19,6 & 19,2 & 21,0 \\
\hline Угорщина & 21,8 & 21,2 & 21,0 & 20,5 & 19,5 & 18,7 & 18,5 & 17,9 & 17,1 & 16,3 \\
\hline
\end{tabular}

Джерело: сформовано на основі даних [12]

Таблиця 3

Основні ставки нарахування платежів на соціальний захист населення

\begin{tabular}{|c|c|c|c|}
\hline \multirow{2}{*}{ Разом, \% } & \multicolumn{2}{|c|}{ \% страхових внесків } & \multirow{2}{*}{ Разом, \% } \\
\hline & Роботодавці & Працівники & \\
\hline Україна & 22 & - & 22 \\
\hline Болгарія & 11,02 & 8,78 & 19,8 \\
\hline Німеччина & 9,3 & 9,3 & 18,6 \\
\hline Естонія & 16 & - & 16 \\
\hline Франція & 8,55 & 6,9 & 15,45 \\
\hline Польща & 9,76 & 9,76 & 19,52 \\
\hline Угорщина & 19,5 & 10 & 29,5 \\
\hline
\end{tabular}

Джерело: сформовано на основі даних [13] 
терієм оцінки розвитку держави, що, в свою чергу, посилить відповідальність платників соціальних внесків. Україна має визначити модель розвитку соціального забезпечення на основі збереження стабільності та відповідальності. Аналізуючи джерела фрормування коштів на покриття витрат соціального забезпечення, стає очевидним, що на сьогодні недоречно розглядати питання про збільшення ставок нарахування платежів на соціальне страхування, що застосовуються до заробітної плати працівників і покриваються за рахунок витрат підприємства. Адже в країнах 3 соціально орієнтованою ринковою економікою відсоток нарахування соціальних внесків $€$ нижчим, ніж в Україні. Угорщина покриває цю різницю за рахунок доходів фрізичних осіб, але розглядати питання щодо збільшення сплати ЄCВ фрізичними особами потрібно в комплексі, окремо аналізуючи податкове навантаження доходів фрізичних осіб, оскільки це може призвести до тінізації доходів.

\section{СПИСОК ВИКОРИСТАНИХ ДЖЕРЕЛ:}

1. Гузенко О., Хайлова Т. Право соціального забезпечення: рольовий сегмент та принципи Соціальні права та їх захист адміністративним судом : матеріали III Міжнар. наук.-практ. конфр. (Київ, 4 вер. 2020 р.). Київ, 2020. С. 21-24. URL: https://rm.coe.int/materials-socialrights-2020/1680a165f8

2. Даніліна М. Конституція України та соціальний захист населення. Соціальні права та їх захист адміністративним судом : матеріали III Міжнар. наук.-практ. конфр. (Київ, 4 вер. 2020 р.). Київ, 2020. С. $25-29$. URL: https://rm.coe.int/materials-socialrights-2020/1680a165f8

3. Дідківська К.В. Актуалізація ролі соціально-етичного маркетингу в сучасних умовах господарювання. Актуальні проблеми економіки. 2009. № 9(99). С. 102-107.

4. Длугопольський О. Державна політика у сфері соціального захисту населення: аспекти відповідальності суспільного сектора. Наука і економіка. 2009. № 4(16). Т. 2. С. 148-156.

5. Конституція України : Закон України від 28.06.1996 № 254к/96-BP. URL: https://zakon.rada.gov.ua/laws/ show/254\%D0\%BA/96-D0\%B2\%D1\%80\#Text

6. Лукащикевич В. Соціальний захист населення України в сучасних умовах: економічні засади. URL: http://lvivacademy.com/vidavnitstvo_1/visnik2/fail/Lukashchykevych.pdf

7. Маршавін Ю.М. Регулювання ринку праці України: теорія і практика системного підходу : монографрія. Київ : Альтерпрес, 2011. 396 с.

8. Мельник К.Ю. Соціально-правовий захист працівників органів внутрішніх справ (проблеми теорії та практики) : дис. ... к. ю. н. Харків, 2003. С. 70-71.

9. Михайловська І., Неліпович О. Система соціального захисту населення в Україні: сутність, основні складові та напрямки вдосконалення. Вісник Хмельницького національного університету. 2011. № 6. Т. 4. С. $255-260$.

10. Новікова О.Ф. Соціальна безпека: організаційно-економічні проблеми і шляхи вирішення. Донецьк : ІЕП НАН України, 1997. 460 с.

11. Кочемировська О.О., Пищуліна О.М. Основні напрями оптимізації системи соціального захисту в Україні : аналіт. доп. Київ : НІСД, 2012. 88 с.

12. Офріційний сайт Євростату. URL: https://ec.europa.eu/eurostat/en/

13. Офріційний сайт Міжнародної асоціації соціального забезпечення. URL: https://ww1.issa.int/ru/

14. Про загальнообов'язкове державне соціальне страхування : Закон України від 23.09.1999 № 1105-XIV. Дата оновлення 21.11.2021. URL: https://zakon.rada.gov.ua/laws/show/1105-14\#Text

15. Руженський М.М. Трансформація інститутів соціального захисту населення в транзитивній економіці : дис. ... докт. екон. наук : 08.00.01. ДВНЗ «Київський національний економічний університет імені Вадима Гетьмана». Київ, 2016. 411 с.

16. Слюсаренко К.В., Садовенко М.М. Соціальна політика ЄС: сучасні виклики та перспективи. Економічний аналіз. 2017. T. 27, № 1. С. 80-90. URL: http://nbuv.gov.ua/UJRN/ecan_2017_27\%281\%29_12

17. Смирнова І.І., Лихошва О.Ю., Рак Н.В., Горієва Л. Соціальний захист населення на сучасному етапі: стан і проблеми в Україні. Економічний вісник Донбасу. 2020. № 3(61). URL: http://evd.luguniv.edu.ua/index.php/ evd/article/view/190

18. Статистичний збірник «Соціальний захист населення України у 2020 році». URL: http://ukrstat.gov.ua/ druk/publicat/kat_u/2021/zb/07/zb_szn_2020.pdf

19. Стельмащук Ю. Особливості зарубіжного досвіду реалізації соціально-гуманітарної політики. Науковий вісник Академії муніципального управління. Серія «Управління». 2016. Вип. 3. С. 174-184.

20. Суханова А.В. Теоретичні підходи до сутності поняття «страховий захист здоров'я». Науковий вісник Херсонського державного університету. Серія : Економічні науки. 2014. Випуск 8. Частина 6. С. 188-192. 


\section{REFERENCES:}

1. Ghuzenko O., Khajlova T. (2020) Pravo socialjnogho zabezpechennja: roljovyj seghment ta pryncypy [Social security law: role segment and principles]. Socialjni prava ta jikh zakhyst administratyvnym sudom: materialy III Mizhnar. nauk.-prakt. konf. (Kyjiv, 4 ver. 2020 r.). Kyiv, pp. 21-24. Available at: https://rm.coe.int/materials-socialrights-2020/1680a165f8 (in Ukrainian)

2. Danilina M. (2020) Konstytucija Ukrajiny ta socialjnyj zakhyst naselennja [Constitution of Ukraine and social protection of the population] Socialjni prava ta jikh zakhyst administratyvnym sudom: materialy III Mizhnar. nauk.-prakt. konf. (Kyiv, 4 ver. 2020 r.). Kyiv, pp. 25-29. Available at: https://rm.coe.int/materials-socialrights-2020/1680a165f8 (in Ukrainian)

3. Didkivsjka K.V. (2009) Aktualizacija roli socialjno-etychnogho marketynghu v suchasnykh umovakh ghospodarjuvannj [Actualization of the role of socio-ethical marketing in modern business conditions]. Aktualjni problemy ekonomiky, no. 9(99), pp. 102-107. (in Ukrainian)

4. Dlughopoljsjkyj O. (2009) Derzhavna polityka u sferi socialjnogho zakhystu naselennja: aspekty vidpovidaljnosti suspiljnogho sektora [State policy in the field of social protection: aspects of public sector responsibility]. Nauka i ekonomika, no. 4(16), t. 2, pp. 148-156. (in Ukrainian)

5. Zakon Ukrajiny Konstytucija Ukrajiny vid 28.06.1996 no. 254 k/96-BP [The Constitution of Ukraine]. Available at: https://zakon.rada.gov.ua/laws/show/254\%D0\%BA/96-\%D0\%B2\%D1\%80\#Text (in Ukrainian)

6. Lukashhykevych V. Socialjnyj zakhyst naselennja Ukrajiny $v$ suchasnykh umovakh: ekonomichni zasady [Social protection of the population of Ukraine in modern conditions: economic principles]. Available at: http://vivacademy.com/vidavnitstvo_1/visnik2/fail/Lukashchykevych.pdf (in Ukrainian)

7. Marshavin Ju.M. (2011) Reghuljuvannja rynku praci Ukrajiny: teorija i praktyka systemnogho pidkhodu [Regulation of the labor market of Ukraine: theory and practice of a systems approach]: monoghrafija. Kyiv: Aljterpres, 396 p. (in Ukrainian)

8. Meljnyk K.Ju. (2003) Socialjno-pravovyj zakhyst pracivnykiv orghaniv vnutrishnikh sprav (problemy teoriji ta praktyky): dys. ... k.ju.n. Kharkiv, pp. 70-71. (in Ukrainian)

9. Mykhajlovsjka I., Nelipovych O. (2011) Systema socialjnogho zakhystu naselennja v Ukrajini: sutnistj, osnovni skladovi ta naprjamky vdoskonalennja [The system of social protection of the population in Ukraine: essence, main components and directions of improvement]. Visnyk Khmeljnycjkogho nacionaljnogho universytetu, no. 6, t. 4, pp. 255-260. (in Ukrainian)

10. Novikova O.F. (1997) Socialjna bezpeka: orghanizacijno-ekonomichni problemy i shljakhy vyrishennja [Social security: organizational and economic problems and solutions]. Donecjk: IEP NAN Ukrajiny, 460 p. (in Ukrainian)

11. Osnovni naprjamy optymizaciji systemy socialjnogho zakhystu v Ukrajini (2012) [The main directions of optimization of the social protection system in Ukraine]: analit. dop. / O.O. Kochemyrovsjka, O.M. Pyshhulina. Kyiv: NISD, 88 p. (in Ukrainian)

12. Oficijnyj sajt Jevrostatu [Official website of Eurostat]. Available at: https://ec.europa.eu/eurostat/en/

13. Oficijnyj sajt Mizhnarodnoji asociaciji socialjnogho zabezpechennja [Official website of the International Social Security Association]. Available at: https://ww1.issa.int/ru/

14. Zakon Ukrajiny Pro zaghaljnoobov'jazkove derzhavne socialjne strakhuvannja vid 23.09.1999 no. 1105-XIV [On compulsory state social insurance]. Available at: https://zakon.rada.gov.ua/laws/show/1105-14\#Text (in Ukrainian)

15. Ruzhensjkyj M.M. (2016) Transformacija instytutiv socialjnogho zakhystu naselennja v tranzytyvnij ekonomici [Transformation of social protection institutions in the transition economy]: dys. ... dokt. ekon. nauk: 08.00.01. DVNZ «Kyivsjkyj nacionaljnyj ekonomichnyj universytet imeni Vadyma Ghetjmana». Kyiv, 411 p. (in Ukrainian)

16. Sljusarenko K.V., Sadovenko M.M. (2017) Socialjna polityka JeS: suchasni vyklyky ta perspektyvy [EU social policy: current challenges and prospects]. Ekonomichnyj analiz, t. 27, no. 1, pp. 80-90. Available at: http://nbuv.gov.ua/UJRN/ecan_2017_27\%281\%29_12 (in Ukrainian)

17.Smyrnova I.I., Lykhoshva O.Ju., Rak N.V., Ghorijeva L.A. (2020) Socialjnyj zakhyst naselennja na suchasnomu etapi: stan i problemy v Ukrajini [Social protection of the population at the present stage: the state and problems in Ukraine]. Ekonomichnyj visnyk Donbasu, no. 3(61). Available at: http://evd.luguniv.edu.ua/index.php/evd/article/view/190 (in Ukrainian)

18. Statystychnyj zbirnyk «Socialjnyj zakhyst naselennja Ukrajiny u 2020 roci» [Statistical collection "Social protection of the population of Ukraine in 2020"]. Available at: http://ukrstat.gov.ua/druk/publicat/kat_u/2021/zb/07/ zb_szn_2020.pdf (in Ukrainian)

19. Steljmashhuk Ju. (2016) Osoblyvosti zarubizhnogho dosvidu realizaciji socialjno-ghumanitarnoji polityky [Features of foreign experience in the implementation of social and humanitarian policy]. Naukovyj visnyk Akademiji municypaljnogho upravlinnja: Serija «Upravlinnja», vol. 3, pp. 174-184. (in Ukrainian)

20. Sukhanova A.V. (2014) Teoretychni pidkhody do sutnosti ponjattja «strakhovyj zakhyst zdorov'ja» [Theoretical approaches to the essence of the concept of "health insurance"]. Naukovyj visnyk Khersonsjkogho derzhavnogho universytetu. Serija: Ekonomichni nauky, vol. 8, ch. 6, pp. 188-192. (in Ukrainian) 